Ks. Waldemar TUREK*

\title{
EXEMPLA STAROTESTAMENTALNYCH KOBIET W INTERPRETACJI PRIMA CLEMENTIS
}

Czytając List do Kościoła w Koryncie św. Klemensa Rzymskiego można odnieść wrażenie, że głównymi sprawczyniami kryzysu we wspólnocie korynckiej były tamtejsze chrześcijanki. List rozpoczyna się od praescriptum, czyli rodzaju wstępu zawierającego podstawowe dane dotyczące autora, adresata i pozdrowienie:

„Kościół Boży w Rzymie do Kościoła Bożego w Koryncie, do tych, którzy zostali powołani i uświęceni w woli Bożej przez Pana naszego Jezusa Chrystusa: Niechaj Bóg wszechmogący użyczy wam przez Jezusa Chrystusa łaski i pokoju w obfitości!"’.

Z przytoczonych słów wynika, że autor kieruje swój List nie do jakiejś części wspólnoty korynckiej, ale do wszystkich wierzących, którzy ją tworzą. Do nich pisze o buncie

„wstrętnym i bezbożnym, który winien być czymś całkiem obcym dla wybranych Boga, a który wznieciło wśród was kilku samowolnych zuchwalców”2.

Biskup Rzymu odwołuje się następnie do chwalebnej przeszłości wspólnoty, opisując stałość wiary poszczególnych jej członków, rozwagę, pobożność, dobroć, gościnność i wiedzę 3 . W odniesieniu do początków gminy korynckiej autor wzmiankuje expressis verbis dwa jej stany: młodzież i kobiety. Gdy chodzi o wiernych korynckich płci żeńskiej, stwierdza:

„Napominaliście też kobiety, by wypełniały wszystkie swe obowiązki z sumieniem nieskazitelnym, świętym i czystym, okazując należną miłość swoim

* Ks. dr hab. Waldemar Turek - professore invitato na Pontificia Università Urbaniana w Rzymie, pracownik Sekretariatu Stanu Stolicy Apostolskiej; e-mail: turek@tiscalinet.it.

${ }^{1}$ Clemens Romanus, Epistula I ad Corinthios, Praescriptum, ed. E. Prinzivalli - M. Simonetti, w: Seguendo Gesù, Testi Cristiani delle Origini (=TCO) 1, Milano 2010, 180, tłum. A. Świderkówna, w: Pierwsi świadkowie, BOK 10, Kraków 1998, 51.

${ }^{2}$ Tamże I 1, TCO 1, 180, BOK 10, 51. Więcej informacji na temat owego buntu por. N. Widok, Droga dażenia do świętości wedtug Klemensa Rzymskiego, VoxP 32 (2012) t. 57, 721-722.

${ }^{3}$ Por. Clemens Romanus, Epistula I ad Corinthios I 2, TCO 1, 180.182, BOK 10, 51. 
mężom. Uczyliście je, jak mają rządzić własnym domem w sposób święty i z wielką roztropnością nie uchylając się nigdy od reguł posłuszeństwa"4.

Przytoczone powyżej oraz inne wypowiedzi z Prima Clementis, które zostaną wskazane w dalszej części niniejszego artykułu, świadczyłyby - zdaniem niektórych współczesnych badaczy - o tym, że kryzys wspólnoty korynckiej został wywołany przede wszystkim przez tamtejsze kobiety. Zdania specjalistów różnią się nieco od siebie w tej kwestii. Christine Trevett twierdzi, że w opinii św. Klemensa Rzymskiego to przede wszystkim roszczenia kobiet korynckich przyczyniły się do powstania publicznego skandalu w tamtejszej wspólnocie i że List został napisany głównie po to, aby przypomnieć niewiastom korynckim ich właściwe miejsce i rolę w Kościele 5 . Odmiennego zdania jest Emanuela Prinzivalli, która dostrzega w Liście pewną tendencję do ograniczenia autonomii kobiet $\mathrm{w}$ gminie korynckiej, ale odrzuca hipotezę C. Trevett, wedle której przywołanie do dyscypliny i posłuszeństwa kobiet korynckich było głównym celem Listu. Zdaniem E. Prinzivalli, jeśli św. Klemens Rzymski dosyć często nawiązuje do roli i misji kobiet, to czyni to przede wszystkim dlatego, aby przypisać kobietom szczególną rolę we wspólnocie chrześcijan, którą wyjaśnia w różnych częściach Listu ${ }^{6}$. W dyskusję dotyczącą tego tematu włączyła się niedawno Gabriella Aragione, która, nawiązując do analiz zaprezentowanych zarówno przez C. Trevett jak i E. Prinzivalli, próbuje podać własną interpretację tekstów Prima Clementis poświęconych postaciom kobiet Starego Testamentu i ich interpretacji przez autora Listu. Autorka przyznaje, że analizy C. Trevett są wnikliwe, ale jednocześnie uznaje, że przypisywanie chrześcijankom ze wspólnoty korynckiej roli wywrotowej w odniesieniu do jej przełożonych nie jest uzasadnione ${ }^{7}$.

Rodzi się zatem uzasadnione pytanie o rzeczywistą rolę, jaką odgrywały kobiety we wspólnocie korynckiej i o ich postrzeganie przez autora Prima Clementis? Czy rzeczywiście uzasadniona jest hipoteza, wedle której były one głównymi sprawczyniami zaistniałych tam trudności? W jaki sposób św. Klemens Rzymski podejmuje w swoim Liście temat kobiety i jej misji i jaką

${ }^{4}$ Tamże I 3, TCO 1, 182, BOK 10, 51.

${ }^{5}$ Por. C. Trevett, Christian Women and the Time of the Apostolic Fathers. Corinth, Rome and Asia Minor, Cardiff 2006, 45: „Shameless female partisanship had contributed to the all-to-public scandal in Corinth"; zob. tamże, 87.

${ }^{6}$ Por. E. Prinzivalli, Commento, w: TCO 1, 455: „L'ipotesi non è del tutto nuova e si fonda sulla constatazione che lo spazio dato in I Clem alle raccomandazioni nei riguardi delle donne è notevole; tuttavia il disciplinamento femminile non può essere lo scopo prevalente della nostra lettera, come sembra sostenere Trevett (p. 87). Parlerei piuttosto della consapevolezza, da parte di I Clem, che le donne giocano un ruolo importante nella comunità".

${ }^{7}$ Por. G. Aragione, La ricezione della Scrittura nei discorsi sulle donne nei secoli I-II, w: Le donne nello sguardo degli antichi autori cristiani. L'uso dei testi biblici nella costruzione dei modelli femminili e la riflessione teologica dal I al VII secolo, ed. K.E. Børresen - E. Prinzivalli, La Bibbia e le Donne, Trapani 2013, 26: „Pur accogliendo le acute osservazioni di Trevett, ritengo che il carattere sovversivo della presenza femminile a Corinto non vada sopravvalutato". 
rolę przypisuje kobiecie we wspólnocie korynckiej i w całym Kościele? Oto pytania, na które postaram się odpowiedzieć analizując te fragmenty Prima Clementis, które są poświęcone postaciom kobiet opisanych w Starym Testamencie i które posłużyły biskupowi Rzymu do nakreślenia, przynajmniej w jakimś zakresie, miejsca i roli kobiet w należycie zorganizowanej wspólnocie wierzących w Chrystusa.

\section{Przykłady (exempla) kobiet Starego Testamentu w interpretacji bis-} kupa Rzymu. Autor Prima Clementis przedstawia niektóre postacie kobiet opisanych w Starym Testamencie, stosując metodę przykładów (exempla), znaną w literaturze starożytnej pogańskiej i chrześcijańskiej; autorzy nawiązywali do przeszłości i przypominali znane figury, aby dać współczesnym sobie przykłady do naśladowania albo przestrzec tychże przed niektórymi błędami. Warto wspomnieć tutaj rolę przypisywaną exemplum przez Senekę: „Przez pouczenia droga jest długa, przez przykłady krótka i skuteczna"8.

Jest rzeczą oczywistą, że pisarze odwoływali się do postaci z przeszłości pod pewnym kątem i w określonym celu: chodziło o taki wybór i ukazanie takich postaw, które odpowiadały poglądom proponowanym przez autora, zgodnie z wyznawanym przez siebie systemem filozoficznym, teologicznym i moralnym. Św. Klemens Rzymski, stosując tego typu metodę, przywołuje z kart biblijnych Starego Testamentu pięć kobiet: Miriam (siostrę Mojżesza i Aarona), żonę Lota, Rachab, Judytę i Esterę.

a) Zazdrosna Miriam. Siostra Mojżesza i Aarona wspomniana jest przez św. Klemensa Rzymskiego jedynie w jednym zdaniu, które brzmi:

„Z powodu zazdrości ( $\Delta$ ì̀ $\zeta \hat{\eta} \lambda \circ \varsigma)$ Aaron i Miriam zostali wygnani z obozu”".

Tym krótkim tekstem biskup odnosi się do długiej historii opisanej w rozdziale 12. Księgi Liczb, dotyczącej wystąpienia Miriam i Aarona przeciw Mojżeszowi. Z biblijnego tekstu wynika, że mówili oni źle o Mojżeszu, za którym jednak wstawił się sam Jahwe:

„I zapalił się gniew Pana przeciw nim. Odszedł Pan, a obłok oddalił się od namiotu, lecz oto Miriam stała się nagle biała jak śnieg od trądu. Gdy Aaron do niej się zwrócił, spostrzegł, że była trędowata. [...] Tak ma być ona przez siedem dni wyłączona z obozu, a potem może znowu powrócić” (Lb 12, 9-10. 14).

Według C. Trevett, postać Miriam ma kluczowe znaczenie dla myśli św. Klemensa Rzymskiego w odniesieniu do trudności wspólnoty korynckiej: kobieta ta reprezentowałaby tamtejsze chrześcijanki, które, pragnąc odgrywać znaczniejszą rolę w lokalnym Kościele, zwłaszcza w dziedzinie prorockiej,

\footnotetext{
${ }^{8}$ Seneca, Epistulae ad Lucilium I 6, 5, ed. L.D. Reynolds, Biblioteca Universale Rizzoli. Classici Greci e Latini, Milano 2014, 76: „Longum iter est per praecepta, breve et efficax per exempla”, tłum. własne.

${ }^{9}$ Clemens Romanus, Epistula I ad Corinthios IV 11, TCO 1, 186, BOK 10, 53.
} 
wystąpiły przeciwko przełożonym tejże wspólnoty ${ }^{10}$. Wzmianka zatem o Miriam, która została wyraźnie przez Boga ukarana, byłaby w wyjaśnieniach św. Klemensa Rzymskiego przestrogą, kierowaną do kobiet korynckich, które przekroczyły zakres swoich uprawnień ${ }^{11}$.

Nieco inne stanowisko prezentuje G. Aragione: według niej, autor Prima Clementis wspomina biblijną historię Miriam przede wszystkim, aby podjąć temat opozycji proroków ,zwykłych” w odniesieniu do proroków o szczególnym posłannictwie, jakim był niewątpliwie Mojżesz ${ }^{12}$. Zdaniem badaczki, w tekście św. Klemensa Rzymskiego chodzi o przywództwo we wspólnocie równych: postawa Aarona i Miriam w interpretacji autora Listu jest wyrazem pewnej rywalizacji mężczyzn i kobiet należących do tego samego ogniska rodzinnego. Wysuwa następnie wniosek, że św. Klemens Rzymski wskazuje tutaj pośrednio na napięcia $\mathrm{w}$ niektórych rodzinach korynckich albo też między nimi na płaszczyźnie społecznej, ekonomicznej czy politycznej ${ }^{13}$.

Wydaje się, że wyjaśnienia zarówno C. Trevett jak i G. Aragione są pewną nadinterpretacją sformułowań św. Klemensa Rzymskiego. Niewątpliwie charakterystyka Miriam jest ostrym oskarżeniem o zazdrość i można dostrzec w niej pewną aluzję do rzeczywistej przyczyny napięcia we wspólnocie korynckiej, która to przyczyna nie odnosiła się jednak jedynie do kobiet. Jeśli bowiem weźmiemy pod uwagę szerszy fragment Prima Clementis, poświęcony zazdrości i zawiści, łatwo się zorientować, że nie brakuje w nim negatywnych przykładów także pośród mężczyzn. Św. Klemens Rzymski wspomina w tym kontekście Kaina, Ezawa, braci Józefa i Saula ${ }^{14}$. Co więcej, św. Klemens Rzymski, podsumowując dłuższy wywód na temat zazdrości, właśnie z zastosowaniem exempla, zauważa:

„Oprócz tych mężów, żyjących tak święcie, pamiętać trzeba jeszcze o całym mnóstwie wybranych, którzy cierpiąc z powodu zazdrości ( $\delta i \grave{\alpha} \zeta \hat{\eta} \lambda \circ \varsigma$ ) rozmaite zniewagi i tortury stali się dla nas najpiękniejszym przykładem

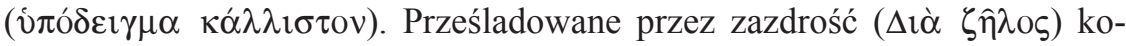
biety, nowe Dirki i Danaidy, ofiary zniewag okrutnych i świętokradczych,

\footnotetext{
${ }^{10}$ Por. Trevett, Christian Women, s. 76: „With the reference to Miriam came an implied warning against the inappropriate involvement of women in such challenge to leadership".

${ }^{11}$ Por. tamże, s. 55: „This story of the prophetic Miriam, like that of Lot's wife (Cor. 11, 1-2), would serve as a warning to «uppity» women in Corinth, who had been exceeding the bond of their proper position".

${ }^{12}$ Por. Aragione, La ricezione della Scrittura, s. 27-28: „La rievocazione del passo non ha come obiettivo la sola Maria, ma il tema dell'opposizione mossa da profeti ordinari nei confronti di un profeta, Mosè, di cui Dio ribadisce il carattere eccezionale (cf. Nm 12, 6-8)".

${ }^{13}$ Por. tamże, s. 28: „Si potrebbe allora formulare l'ipotesi secondo cui l'episodio di Aronne e Maria evocherebbe casi di competizione o, meglio, di rivendicazioni espressi da uomini e donne, appartenenti a uno stesso nucleo famigliare, nei confronti di altri componenti della stessa famiglia".

${ }^{14}$ Por. Clemens Romanus, Epistula I ad Corinthios IV 1-13, TCO 1, 184-186, BOK 10, 52-53.
} 
przebiegły pewnym krokiem całą drogę wiary i mimo słabości swego ciała zdobyły chwalebną nagrodę"15.

Nie wydaje się w kontekście tego stwierdzenia, aby przytoczone wcześniej zdanie o Miriam upoważniało do przypisywania kobietom korynckim głównej odpowiedzialności za rozruchy w tamtejszej wspólnocie. Należy je wyjaśniać z uwzględnieniem wywodu św. Klemensa Rzymskiego na temat zła zazdrości, jak to ukazują exempla zarówno w odniesieniu do mężczyzn jak i kobiet. Ponadto, zdaniem autora Listu, kiedy cierpimy z powodu zazdrości innych, możemy zostać umocnieni w wierze i, w konsekwencji, zdobyć chwalebną nagrodę. Exempla nam pokazują, że ci, którzy cierpieli, ponieważ inni im zazdrościli, stali się dla wszystkich najpiękniejszym przykładem ( кó $\lambda \lambda \iota \sigma \tau o v)$. Św. Klemens Rzymski kreśli tutaj obraz idealnej kobiety chrześcijańskiej, która nie tylko nie zazdrości, ale potrafi zachować wiarę wobec cierpień spowodowanych zazdrością innych.

b) Chwiejna i wątpiąca żona Lota. Nieco dłuższa w porównaniu z wypowiedzią o Miriam jest charakterystyka odnosząca się do żony Lota:

„Dzięki swej gościnności i pobożności Lot został ocalony z Sodomy, chociaż całą krainę pokarał Bóg ogniem i siarką. Pokazał Pan z całą jasnością, że nie opuszcza tych, którzy w Nim pokładają nadzieję, tych natomiast, co gdzie indziej szukają oparcia, wydaje na karę i udrękę. Znakiem stała się tutaj żona Lota. Towarzyszyła mu ona wprawdzie w ucieczce, lecz nie dzieliła jego wiary i nie była z nim zgodna. Zamieniona w słup soli, aż do dnia dzisiejszego

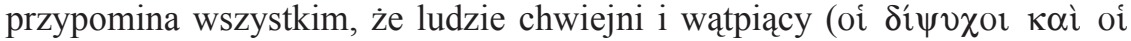
$\delta 1 \sigma \tau \alpha ́ \zeta o v \tau \varepsilon \varsigma)$ w moc Bożą muszą być ukarani, by stać się ostrzeżeniem dla przyszłych pokoleń"16.

Lot i jego żona ukazani są w tekście św. Klemensa Rzymskiego jako postacie absolutnie odmienne $\mathrm{z}$ punktu widzenia duchowego. Lot jest chwalony za gościnność, pobożność i nadzieję pokładaną w Bogu. Gdy chodzi natomiast o jego żonę, biskup Rzymu szuka pozytywnych aspektów w jej zachowaniu, ale może ją pochwalić jedynie za to, że towarzyszyła mężowi w ucieczce. Zarzuca jej natomiast przede wszystkim brak wiary i brak zgodności z mężem. Z przytoczonego fragmentu wynika także, że była ona osobą chwiejną i wątpiącą w moc Bożą; nic więc dziwnego, że została ukarana i stała się ostrzeżeniem dla przyszłych pokoleń.

Warto w tym miejscu dodać, że postać żony Lota, z racji przede wszystkim na jej nieposłuszeństwo, brak ufności i poniesioną karę, interesowała już niektórych autorów Starego i Nowego Testamentu. Wystarczy przytoczyć słowa Księgi Mądrości:

\footnotetext{
15 Tamże VI 1-2, TCO 1, 188, BOK 10, 53.

16 Tamże XI 1-2, TCO 1, 194, BOK 10, 55-56.
} 
„Jeszcze jako świadectwo ich przewrotności: pozostało dymiące pustkowie, rośliny owocujące o niezwykłej porze i sterczący słup soli, pomnik duszy, co nie dowierzała" $(10,7)$.

Zaś w Ewangelii według św. Łukasza czytamy słowa Chrystusa, który, mówiąc o dniach ostatecznych, przywołuje interesującą nas postać:

„W owym dniu, kto będzie na dachu, a jego rzeczy w mieszkaniu, niech nie schodzi, by je zabrać; a kto na polu, niech również nie wraca do siebie. Miejcie w pamięci żonę Lota!” (17, 31-32).

Przytoczone fragmenty Prima Clementis i Ewangelii św. Łukasza są najstarszymi tekstami chrześcijańskimi, w których jest mowa o żonie Lota. To co najbardziej uderza we wszystkich przytoczonych tekstach, to brak wiary ze strony żony Lota, jak też pewna chwiejność i podzielone, czyli nieszczere serce ( $\delta \imath \psi v \chi i \alpha)$; to ono sprawia, że trudno jest zachować jedność ze wspólnotą. Św. Klemens Rzymski rozwija ten temat w innej części Listu, w której, używając zachęty wyrażonej w pierwszej osobie liczby mnogiej, zwraca się do wszystkich wierzących w Chrystusa:

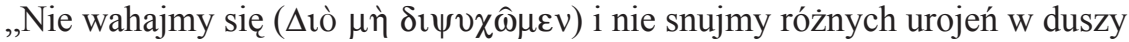
tam, gdzie chodzi o tak wielkie i chwalebne Jego dary. Niechaj nigdy nie od-

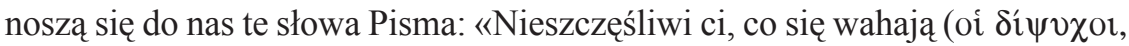
oi $\delta 1 \sigma \tau \alpha ́(o v \tau \varepsilon \varsigma)$ i wątpiąc w duszy mówią: Obietnice te słyszeliśmy już i za czasów ojców naszych, a oto dożyliśmy starości i zestarzeliśmy się i nic z tego się nam nie wydarzyło»" ${ }^{17}$.

Wydaje się, że interesujące nas wyrażenie $\Delta$ iò $\mu \grave{\eta} \delta \imath \psi v \chi \hat{\omega} \mu \varepsilon v$ bardziej niż „nie wahajmy się” należałoby przetłumaczyć: „Nie miejmy serca podzielonego" albo „Nie bądźmy podzieleni w duszy”. Św. Klemens Rzymski bowiem zwraca uwagę na fakt, że prostota serca pomaga pokonać niepewność i niewdzięczność wobec darów Bożych, obficie proponowanych wierzącym w Niego. Jako ciekawostkę należy dodać, że przytoczony przez autora w sposób uroczysty cytat, rzekomo biblijny, nie znajduje się ani w Piśmie Świętym, ani w znanych dotychczas apokryfach ${ }^{18}$.

Krótka charakterystyka żony Lota zaprezentowana przez autora Listu nie upoważnia do uzasadnienia hipotezy, wedle której kobiety ze wspólnoty korynckiej były głównymi sprawczyniami powstałych w niej zamieszek. Owszem, św. Klemens Rzymski zarzuca jej chwiejność, brak wiary i podzielone serce, ale te same słabości dostrzega też u innych wiernych Koryntu.

c) Wierna i gościnna Rachab. Biblijny epizod o Rachab jest szczegółowo opisany przez św. Klemensa Rzymskiego; żadnej innej postaci niewieściej

${ }^{17}$ Tamże XXIII 2-3, TCO 1, 214-216, BOK 10, 62.

${ }^{18}$ Por. Prinzivalli, Commento, s. 486: „La citazione, introdotta nel modo più solenne come scritturistica, non trova riscontro in nessun libro canonico e neppure apocrifo". 
nie poświęca on tak dużo miejsca i uwagi, żadnej innej nie wychwala do tego stopnia. Oto istotny dla nas fragment opisu:

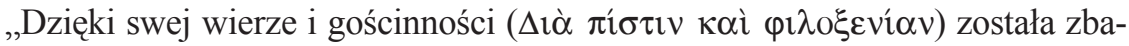
wiona nierządnica Rachab. Jozue, syn Nuna, wyprawił do Jerycha szpiegów. A kiedy król tej ziemi dowiedział się, że przyszli, by zrobić wywiad w jego kraju, posłał wówczas ludzi, którzy mieli ich pojmać, a pojmanych zabić. Gościnna Rachab przyjęła ich w swym domu i ukryła na piętrze pod łodygami lnu"19.

Rachab jest chwalona przez św. Klemensa Rzymskiego przede wszystkim za wiarę $(\pi i \sigma \tau \imath \varsigma)$ i za gościnność ( $\varphi \imath \lambda \circ \xi \varepsilon v i ́ \alpha)$; te dwie cechy są szczególnie ważne dla autora Listu. One sprawiły, że Rachab została uratowana przez Boga, przewidując w jakiś tajemniczy sposób, może nawet prorocki, że On postanowił dać ten kraj swojemu narodowi. Wychwalając wiarę i gościnność Rachab, autor opiera się, przynajmniej w jakiejś mierze, na tradycji biblijnej, ukazującej te same przymioty bohaterki starotestamentalnej. Czytamy w Liście do Hebrajczyków:

„Dzięki wierze nierządnica Rachab nie zginęła razem z niewierzącymi, bo gościnnie przyjęła wysłanych na zwiady" $(11,31)$.

Zaś w Liście św. Jakuba znajdujemy słowa:

„Widzicie, że człowiek dostępuje usprawiedliwienia na podstawie uczynków, a nie samej tylko wiary. Podobnie też nierządnica Rachab, która przyjęła wysłanników i inną drogą odprawiła ich, czy nie dostąpiła usprawiedliwienia na podstawie swoich uczynków?" $(2,24-25)$.

Podkreślanie znaczenia wiary przez św. Klemensa Rzymskiego jest zrozumiałe samo przez się i nie wymaga dodatkowych wyjaśnień. Może natomiast zaskakiwać nieco przypisywanie tak dużej roli gościnności Rachab. Być może, w klimacie niepewności, prześladowań i bezpośredniego zagrożenia $\varphi \imath \lambda o \xi \varepsilon v i ́ \alpha$ nie oznacza jedynie zwykłej gościnności, ale także tej, która wymaga narażenia i odwagi, jak to było w przypadku Rachab. W Liście bowiem wyczuwa się klimat zagrożenia; odnosi się wrażenie jakoby niebezpieczeństwo było bliskie i chodziłoby nie tylko o potrzebę gościnności w dosłownym tego słowa znaczeniu, ale także solidarności, współpracy i jedności między chrześcijanami, zwłaszcza w obliczu ataków ze strony przedstawicieli i instytucji Cesarstwa ${ }^{20}$.

Obok wiary i gościnności, św. Klemens Rzymski przypisuje Rachab, przynajmniej w jakimś stopniu, dar proroctwa. Oto odnośny fragment:

${ }^{19}$ Clemens Romanus, Epistula I ad Corinthios XII 1-3, TCO 1, 196, BOK 10, 56.

${ }^{20}$ Por. Aragione, La ricezione della Scrittura, s. 32-33: „Nel corso della Lettera le allusioni a un clima di insicurezza, di persecuzione, di pericolo imminente, sono tali da far pensare che la $\varphi \imath \lambda o \xi \varepsilon v i ́ \alpha$ non si riferisca solo all'ospitalità offerta agli itineranti, ma anche alla necessità di creare una rete di solidarietà per proteggere i credenti presi di mira dalle autorità politiche". 
„Poradzili jej jeszcze, żeby jako znak wywiesiła ze swego domu sznur szkarłatny. W ten sposób wskazywali, że wszyscy, którzy wierzą i pokładają nadzieję w Bogu, dostapią odkupienia przez krew Pana. Widzicie, umiłowani moi, że kobieta ta miała nie tylko wiarę ( $\pi \dot{i} \sigma \tau \iota \varsigma)$, ale i dar proroctwa ( $\pi \rho \circ \varphi \eta \tau \varepsilon i ́ \alpha){ }^{\prime 21}$.

Jest rzeczą charakterystyczną, że w całym swoim Liście św. Klemens Rzymski używa rzeczownika $\pi \rho \circ \varphi \eta \tau \varepsilon i ́ \alpha$ jedynie raz, właśnie w odniesieniu do Rachab.

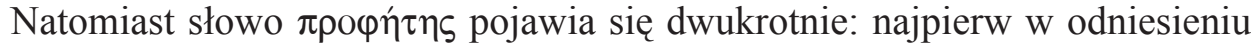
do Eliasza, Elizeusza i Ezechiela ${ }^{22}$, a następnie w odniesieniu do Mojżesza ${ }^{23}$. Świadczy to o tym, że temat proroctwa nie jest przez autora Listu szczegółowiej omawiany; być może biskup uważał, że nie ma potrzeby zajmować się bliżej argumentem, który chrześcijanom korynckim był dobrze znany. Tym większe zatem ma znaczenie odniesienie rzeczownika $\pi \rho \varphi \eta \tau \varepsilon i ́ \alpha$ właśnie do Rachab. Ale i w jej przypadku św. Klemens Rzymski nie precyzuje, czego konkretnie dotyczył ten dar. $Z$ tekstu nie wynika, że Rachab prowadziła jakąś działalność prorocką i zapowiadała przyszłe wydarzenia; raczej odznaczała się wewnętrznym przeczuciem, że kraj wcześniej czy później będzie zdobyty przez naród wybrany, bo tak Pan zdecydował. Rachab jest co do tego przekonana i podejmuje decyzje $\mathrm{z}$ uwagi na to przekonanie; postanawia pomóc wysłannikom narodu wybranego, mimo że to łączyło się z niebezpieczeństwem, i za to zostaje wynagrodzona. Rachab jednak jest uratowana przez Boga nie $\mathrm{z}$ racji na dar proroctwa, ale dzięki posłuszeństwu i wierze ${ }^{24}$.

Jeśli porównuje się postawę Rachab z postawą żony Lota, dostrzega się najpierw fakt, że chodzi o osoby pochodzące $\mathrm{z}$ różnych klas społecznych; to jednak nie ma większego znaczenia dla św. Klemensa Rzymskiego. Dla niego liczą się przede wszystkim aspekty duchowe, zwłaszcza wiara i gościnność, czyli relacja do Boga i do bliźniego. Żona Lota nie odznaczała się tymi przymiotami i wątpiła w moc Boża, dlatego została ukarana; Rachab natomiast jest przedstawiona niemal jako bohaterka i wzór do naśladowania; o jej słabościach (przecież była nierządnica) św. Klemens Rzymski w ogóle nie wspomina. Daje natomiast wyraźny sygnał wszystkim adresatom swojego Listu, że wiara i nadzieja w Bogu będą zawsze wynagrodzone.

d) Kochająca ojczyznę i lud Judyta. Wspominając Judytę, św. Klemens Rzymski podkreśla przede wszystkim jej patriotyzm:

„Niemało kobiet umocnionych łaską Bożą dokonało czynów godnych męża.

Błogosławiona Judyta w czasie oblężenia miasta uprosiła Starszych, by

${ }^{21}$ Clemens Romanus, Epistula I ad Corinthios XII 7-8, TCO 1, 196, BOK 10, 56.

${ }^{22}$ Por. tamże XVII 1, TCO 1, 204, BOK 10, 59.

${ }^{23}$ Por. tamże XLIII 1, TCO 1, 240, BOK 10, 70 .

${ }^{24}$ Podobnie interpretuje ten temat A. Jaubert, SCh 167, Paris 1971, 121, nota 7: „Reprise du thème fondamental: l'obéissance et la foi supposent l'humilité. Cependant l'enchaînement est réel avec l'épisode de Rahab qui n'a pas été sauvée par le don de prophétie mais par la soumission au signe du salut. La suite montre qu'aucun don - même spirituel - ne sauve". 
pozwolili jej pójść do obozu nieprzyjaciół. Narażając się dobrowolnie na niebezpieczeństwo wyszła wiedziona miłością ojczyzny i swojego oblężonego ludu i wydał Pan Holofernesa w ręce kobiety"25.

W dwóch zdaniach św. Klemens Rzymski przedstawia historię Judyty, której postać jest szczegółowo opisana w księdze noszącej jej imię. Warto pokrótce, dla lepszego zrozumienia przytoczonego tekstu biskupa, przypomnieć jak jej losy zostały opisane w Biblii. Wcześnie owdowiała, miała 14 synów, była piękna, bogata, bardzo pobożna, pomagała ludziom potrzebującym. W czasie najazdu wojsk asyryjskich na Izrael, ich wódz Holofernes oblegał miasto Betulię, którego klęska była przesądzona. Wówczas Judyta postanowiła bronić miasta. Po wieczornej modlitwie udała się do obozu Asyryjczyków, wyjaśniając im, że opuściła miasto chcąc ocalić życie. Kiedy zaprowadzono ją przed oblicze Holofernesa, ten zakochał się w niej będąc pod wrażeniem jej urody i zabrał ją do swojego namiotu. Czwartego dnia po wielkiej uczcie, gdy Holofernes zasnął, Judyta ucięła mu głowę, włożyła ją do kosza i powróciła do Betulii. O świcie wywieszono głowę na murach miasta. Gdy ją ujrzało wojsko asyryjskie, zaczęło uciekać w popłochu i zostało rozgromione przez Izraelitów.

Św. Klemens Rzymski nie wnika w szczegóły życia i działalności Judyty, a przecież mógłby pochwalić ją za pobożność, pomoc okazywaną innym i za odwagę. Zaznacza natomiast w odniesieniu do Judyty, podobnie jak do Estery, że umocniona łaską Bożą dokonała czynów godnych męża. Dla współczesnego czytelnika może się to wydawać rzeczą oczywista, ale w czasach św. Klemensa Rzymskiego tego typu stwierdzenie miało szczególną wymowę. Umieszczenie na tym samym poziomie możliwości kobiet i mężczyzn było wyrazem bardzo pozytywnego spojrzenia na rolę niewiasty we wspólnocie wierzących.

Jak już wspomniano, biblijny opis życia i czynów Judyty jest o wiele bogatszy niż opis życia i działalności poprzednio wymienionych bohaterek. Jednak św. Klemens, przedstawiając Judytę, pomija, w większym stopniu niż to miało miejsce $w$ innych przypadkach, wiele wydarzeń z jej życia uwzględnionych w Piśmie Świętym. Zwracając uwagę na te, które są mu przydatne do przedstawienia niektórych cech, jakimi powinna się charakteryzować wierząca kobieta, podkreśla przede wszystkim fakt, że Judyta działała za pozwoleniem przełożonych, że naraziła się na niebezpieczeństwo i że kierowała się miłością do ojczyzny i do swojego ludu.

Brak szczegółów biblijnych może być wyjaśniony tym, że adresaci $L i$ $s t u$ znali dobrze historię Judyty, jej życia i działalności; jednak wybór przedstawianych tematów z bogatego życia starotestamentalnej bohaterki i ich interpretacja nie są przypadkowe. Nie bez znaczenia jest fakt, że św. Klemens Rzymski pominął, przykładowo, aspekty fizycznego piękna Judyty i metody jej działania, w których ważną rolę odegrały uwodzicielstwo i przebiegłość. Skupił się natomiast na miłości ojczyzny i oblężonego ludu, z racji na którą

\footnotetext{
${ }^{25}$ Clemens Romanus, Epistula I ad Corinthios LV 3-5, TCO 1, 256, BOK 10, 76.
} 
Bóg wydał Holofernesa „w ręce kobiety”. Znaczące jest to ostatnie wyrażenie, które znajduje swoje uzasadnienie w samej Księdze Judyty:

„Uderz podstępem warg moich niewolnika obok wodza i wodza obok jego sługi. Skrusz ich zarozumiałość ręką niewiasty!” $(9,10)$.

„Lecz Pan Wszechmogący pokrzyżował im szyki ręką niewiasty” $(16,15)$.

Biblijne wyrażenia, wykorzystane przez autora Listu, wyraźnie ukazują, że podmiotem działania jest zawsze Bóg, a Judyta przedstawiona została jako narzędzie, przez które działa Wszechmogący. Czy rzeczywiście św. Klemens Rzymski w nieco innym tonie przedstawił postać Judyty, ponieważ kobiety korynckie (i rzymskie) właśnie na nią się powoływały, domagając się większej autonomii w działaniu, a autor Listu, pragnąc wystąpić przeciwko tego typu tendencjom, zinterpretował jej postawę w inny sposób, podkreślając przede wszystkim ofiarę z samej siebie, jaką złożyła Judyta?

Nie przekonują argumentacje, wedle których kobiety korynckie i rzymskie dostrzegały w Judycie przykład i wzór do naśladowania, jak też argument na rzecz większych ich uprawnień we wspólnotach chrześcijańskich. Brakuje w tym względzie świadectw. Św. Klemens Rzymski nieprzypadkowo zwraca uwagę na fakt, że Judyta poprosiła Starszych o autoryzację do podjęcia działania. Temu faktowi, zgodnemu z przekazem biblijnym (por. Jdt 8, 35), autor Listu przypisuje szczególne znaczenie, zachęcając adresatów do działania w zgodzie z przełożonymi. Jednak jeszcze większe znaczenie ma dla biskupa Rzymu fakt, że Judyta działała w zgodzie z wolą Boga, który wydał w jej ręce Holofernesa. Te dwie charakterystyki działania Judyty są zasadnicze dla myśli św. Klemensa Rzymskiego: odczytanie woli Bożej i prośba o autoryzację działania przez Starszych sprawiają, że jest ona, owszem, ukazana jako wzór działania dla kobiet rzymskich i korynckich, ale w innym ujęciu niż by chcieli niektórzy współcześni badacze Prima Clementis.

e) Doskonala w wierze Estera. Charakteryzując kolejną niewiastę ze Starego Testamentu, autor Listu zauważa:

„Nie mniejsze niebezpieczeństwo ściągnęła na swoją głowę doskonała w wie-

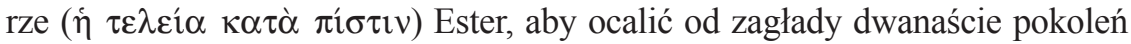
Izraela. Błagała wśród postów i w uniżeniu wszystkowidzącego Pana wieków, a On ujrzawszy pokorę jej duszy ocalił lud, dla którego na śmierć się naraziła"26.

Według opisu Księgi Estery, wielki władca Aswerus, oddaliwszy swą żonę Waszti, wybrał na nową małżonkę Esterę, nie wiedząc o jej żydowskim pochodzeniu. Wezyr królestwa, Haman, wróg Mardocheusza, stryjecznego brata Estery, zaplanował zagładę wszystkich Żydów na terenie Persji. Estera udaremniła ten plan swoją interwencją, uzyskując od króla wyrok śmierci na Hamana i nieprzyjaciół Żydów, a dla Mardocheusza godność wezyra.

\footnotetext{
${ }^{26}$ Tamże LV 6, TCO 1, 258, BOK 10, 76.
} 
W ujęciu Estery, zaproponowanym przez św. Klemensa Rzymskiego, dostrzega się przede wszystkim jej niezwykłą odwagę i doskonałą wiarę. Działanie starotestamentalnej bohaterki łączy się z wielkim niebezpieczeństwem w odniesieniu do niej samej jak i do całego jej narodu; jest aktem bohaterstwa, połączonego z głęboką rozwaga, choć nie bez ryzyka. To co jednak ma szczególne znaczenie dla św. Klemensa Rzymskiego, to fakt, że Estera podjęła się ryzykownego działania nie dla swojego ocalenia, ale dla ocalenia dwunastu pokoleń izraelskich, czyli całego narodu wybranego. Warto zwrócić uwagę na ten aspekt; autor wybiera go z wielu innych charakterystyk Estery, przedstawionych w biblijnej księdze jej poświęconej.

Jednak największą zaletą Estery, w ujęciu św. Klemensa Rzymskiego, była jej wiara; nią się kierowała przede wszystkim podejmując ryzykowne decyzje. Nie bez powodu Estera została nazwana przez św. Klemensa Rzymskiego

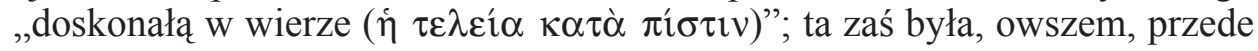
wszystkim Bożym darem, ale też wynikiem różnego rodzaju wyrzeczeń w życiu starotestamentalnej bohaterki, zwłaszcza postu i jej uniżenia, czyli pokory wobec Boga. Niewątpliwie tego typu praktyki sprawiły, że Bóg umocnił ją w wierze, dał jej rozsądek i odwagę do podejmowania ryzykownych działań. Estera wierzyła w Boga, który wszystko wie i widzi. W rzeczywistości:

„Błagała wśród postów i w uniżeniu wszystkowidzącego ( $\pi \alpha \nu \tau \varepsilon \pi$ ó $\pi \tau \eta$ ) Pana wieków"27.

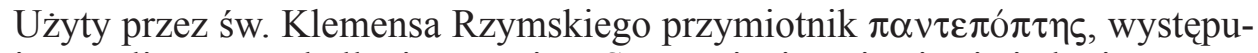
jący w literaturze hellenistycznej, w Septuagincie pojawia się jedynie w Drugiej Księdze Machabejskiej: „Ale wszystkowidzący ( $\pi \alpha \nu \tau \varepsilon \pi$ ó $\pi \tau \eta \zeta)$ Pan, Bóg Izraela, dotknął go nieuleczalnym i niewidocznym cierpieniem" (2Mch 9, 5). To samo słowo nie zostało natomiast użyte ani raz w Nowym Testamencie. Można jednak przypuszczać, że adresaci Listu znali dobrze znaczenie tego terminu, który przypominał im podstawowy skądinąd fakt o doskonałej wiedzy, jaką Bóg posiada w odniesieniu do ich myśli, słów i czynów, i że nie ominą ich konsekwencje ich działania.

Doskonała w wierze i podejmująca wyrzeczenia Estera, odznaczała się też szczególną pokorą:

„A On ujrzawszy pokoręjej duszy ocalił lud, dla którego na śmierć się naraziła”28.

Św. Klemens Rzymski mówi wielokrotnie w swoim Liście o pokorze, zwracając uwagę na różne aspekty tej ważnej dla chrześcijan postawy ${ }^{29}$. Szczególnie donośne dla autora wydaje się stwierdzenie, wedle którego pokora jest konsekwencją wiary i posłuszeństwa. Estera jest doskonałym biblijnym

27 Tamże.

${ }^{28}$ Tamże LV 6, TCO 1, 258, BOK 10, 76.

${ }^{29}$ Szczególnie ważne w tej materii są rozdziały Clemens Romanus, Epistula I ad Corinthios od XIII 1 do XIX 1, TCO 1, 198-210, BOK 10, 56-60. 
exemplum tego typu postawy: odznacza się głęboką wiarą i posłuszeństwem oraz, konsekwentnie, pokora. Bóg dostrzegając te przymioty, podobnie jak jej odwagę i narażenie, ocalił lud, do którego należała.

2. Exempla: ich rola i cel w Prima Clementis. Dlaczego św. Klemens Rzymski w Liście pisanym do wspólnoty korynckiej nawiązuje do niektórych postaci kobiet Starego Testamentu? Czy rzeczywiście dlatego, że wierne korynckie były głównymi sprawczyniami zaistniałego tam kryzysu i chodziło o to, aby im ukazać, na podstawie exempla, czego mają unikać w życiu duchowym i w codziennym postępowaniu, a co pielęgnować i rozwijać? Aby odpowiedzieć na te pytania, trzeba teraz, po przyjrzeniu się charakterystyce postaci kobiet ze Starego Testamentu w Prima Clementis, wrócić do tekstu przytoczonego na początku niniejszego artykułu:

„Napominaliście też kobiety, by wypełniały wszystkie swe obowiązki z sumieniem nieskazitelnym, świętym i czystym, okazując należną miłość swoim mężom. Uczyliście je, jak mają rządzić własnym domem w sposób święty i z wielką roztropnością nie uchylając się nigdy od reguł posłuszeństwa" ${ }^{30}$.

Znamienne jest podkreślenie potrzeby działania według sumienia, opisanego trzema przymiotnikami: nieskazitelne, święte i czyste. To stwierdzenie może być uznane za złotą regułę myślenia i działania. Po jej sformułowaniu, św. Klemens Rzymski przypomina w sposób konkretny, że kobiety mają okazywać należną miłość mężom, że mają rządzić własnym domem i nie uchylać się nigdy od reguł posłuszeństwa. Biskup przypisuje zatem kobietom nie tylko obowiązek posłuszeństwa, ale też rolę aktywną, kiedy mówi, że mają kierować domem w sposób święty i z wielką roztropnością. Czy to jednak trochę nie za mało dla kobiet korynckich tamtego okresu?

Niewątpliwie można tutaj dostrzec zachętę do dyscypliny i pewne ograniczenie przestrzeni zarezerwowanej dla kobiet, ale, jeśli te słowa rozpatrywane są w ówczesnym kontekście społecznym i religijnym, nie mogą stanowić głównej przyczyny powstania Listu. Św. Klemens Rzymski jest świadom tego, że kobiety odgrywają doniosłą rolę we wspólnocie wierzących, tak jak to było w przypadku podanych wcześniej exempla ze Starego Testamentu. Nie bez powodu autor Listu używa w przytoczonym tekście drugiej osoby liczby mnogiej; niektórzy interpretatorzy chcieli w tym zaimku widzieć przede wszystkim przywódców rodzin ${ }^{31}$. Nie ma podstaw, by zaprzeczać całkowicie tego typu opinii, jednak św. Klemens Rzymski, jak widać to już w praescriptum i w kilku innych fragmentach Listu, kieruje pismo do całej wspólnoty,

${ }^{30}$ Tamże I 3, TCO 1, 182, BOK 10, 51.

${ }^{31}$ Por. J.S. Jeffers, Jewish and Christian Families in First-Century Rome, w: Judaism and Christianity in First-Century Rome, ed. K.P. Donfried - P. Richardson, Grand Rapids (Michigan) 1998, 140; Trevett, Christian Womens, s. 46. 
wymieniając - w zależności od potrzeby i podejmowanego tematu - poszczególne jej stany, jak to dostrzega się jeszcze wyraźniej w poniższym tekście:

„Czcijmy Pana Jezusa Chrystusa, którego krew została za nas wylana, szanujmy naszych zwierzchników, poważajmy starszych, młodych wychowujmy w bojaźni Bożej, a żony nasze kierujmy ku dobremu. Niechaj będą one dla wszystkich zwierciadłem czystości obyczajów, niech dowodzą, że szczerze dążą do łagodności, niech swym milczeniem świadczą o wstrzemięźliwości języka, a miłością, nie kształtowaną ludzkimi skłonnościami, obejmują na równi wszystkich, którzy żyją w bojaźni Boga" ${ }^{\text {"2 }}$.

Biskup Rzymu wymienia przełożonych, starszych, młodzież i żony; zachęca te ostatnie do przestrzegania czystości obyczajów, łagodności, milczenia i miłości $^{33}$. Łatwo tutaj można dostrzec różnice między poprzednimi tekstami, kreującymi idealny obraz kobiet we wspólnocie chrześcijańskiej, a tym fragmentem, w którym wyraźnie dostrzega się u nich pewne braki; $\mathrm{z}$ jednej strony mamy zatem pewien obraz, z drugiej zaś konkretną sytuację, którą trzeba naprawić przez zarysowanie pewnego ideału ${ }^{34}$. Temu ma służy cały List, skierowany do wszystkich wiernych korynckich i nie tylko, stanowiący wymowne i bogate treściowo świadectwo troski św. Klemensa Rzymskiego o właściwy, uporządkowany rozwój gmin chrześcijańskich, działających w różnych częściach świata.

Niektóre kobiety opisane w Starym Testamencie są w interpretacji św. Klemensa Rzymskiego postaciami negatywnymi: Miriam jest krytykowana za zazdrość, żona Lota za to, że była chwiejna i wattpiąca. Autor Listu chwali natomiast Rachab za jej wierność i gościnność, Judytę za to, że kochała ojczyzną i lud, oraz Esterę za jej doskonałą wiarę. Nawiązując do przeszłości opisanej w Biblii i prezentując poszczególne exempla, znane chrześcijańskiej wspólnocie korynckiej, biskup Rzymu bierze pod uwagę jej aktualną sytuację i zwraca uwagę na wybrane przez siebie cechy bohaterek Starego Testamentu, ukazywane jako ciaggle aktualne nie tylko dla wiernych korynckich ale wszystkich wierzących. Wydaje się w tym kontekście, że główną przyczyną powstania Listu, kierowanego do wszystkich wiernych korynckich, nie była postawa tamtejszych chrześcijanek, domagających się rzekomo większych uprawnień w Kościele, ile nakreślenie, z uwzględnieniem rzeczywistych trudności chrześcijan korynckich, obrazu idealnej wspólnoty, działającej w Koryncie,

${ }^{32}$ Clemens Romanus, Epistula I ad Corinthios XXI 6-7, TCO 1, 212-214, BOK 10, 61.

${ }^{33}$ Por. C. Mazzucco, I Padri Apostolici, w: Donna e matrimonio alle origini della Chiesa, a cura di E. dal Covolo, Biblioteca di Scienze Religiose 122, Roma 1996, 28-29.

${ }^{34}$ Por. Prinzivalli, Commento, s. 485: „In altri termini, una cosa è la visione androcentrica vagheggiata dall'autore, un'altra la realtà di fatto, rispetto alla quale egli dà indicazioni perché le donne corinzie (come possiamo immaginare, quelle romane) si comportino al meglio". 
w Rzymie czy w jakimkolwiek innym miejscu. W tej wspólnocie ma istnieć określony porządek i harmonia, tak jak to się dzieje we wszechświecie stworzonym przez Boga, i każdy ze stanów ma w niej swoje miejsce i swoją rolę do spełnienia. Kobiety mają unikać zazdrości i chwiejności w wierze, natomiast troszczyć się o głęboką wiarę, gościnność, miłość ojczyzny i ludu.

\section{THE EXEMPLA OF OLD TESTAMENT WOMEN IN THE INTERPRETATION OF PRIMA CLEMENTIS}

\section{(Summary)}

Some scholars have recently tried to show that the problems in the Christian community at Corinth were caused in a particular way by women wishing to have a more significant role within the community, and that the primary purpose of Saint Clement's Letter to the Corinthians was to bring them to order and to show them their proper place in the community's life and activity. The current study primarily tries to show that Prima Clementis was addressed to the entire Corinthian community. This is followed by an analysis of the passages in which Saint Clement presents the feminine figures of the Old Testament: Miriam (the sister of Moses and Aaron), Lot's wife, Rahab, Judith, and Esther, and interprets them in the context of the Christian situation at Corinth. In this way, it is shown that Clement, by using the exempla method, creates the image of a perfect, ordered, and harmonious community in which women are outstanding for their strong faith, love, and hospitality.

Key words: praescriptum, exempla, jealousy, wavering in faith, fidelity, hospitality, love of homeland, love of neighbor, perfect faith, harmony.

Słowa kluczowe: praescriptum, exempla, zazdrość, chwiejność w wierze, wierność, gościnność, miłość ojczyzny, miłość bliźniego, wiara doskonała, harmonia.

\section{BIBLIOGRAFIA}

\section{Źródła}

Clemens Romanus, Epistula I ad Corinthios, ed. E. Prinzivalli - M. Simonetti, w: Seguendo Gesù, Testi Cristiani delle Origini (= TCO) 1, Milano 2010, 180-274, thum. A. Świderkówna, w: Pierwsi świadkowie, BOK 10, Kraków 1998, 51-81.

SenecA, Epistulae ad Lucilium, ed. L.D. Reynolds, Biblioteca Universale Rizzoli. Classici Greci e Latini, Milano 2014.

\section{Opracowania}

Aragione G., La ricezione della Scrittura nei discorsi sulle donne nei secoli I-II, w: Le donne nello sguardo degli antichi autori cristiani. L'uso dei testi biblici nella costruzione dei modelli femminili e la riflessione teologica dal I al VII secolo, ed. K.E. Børresen - E. Prinzivalli, La Bibbia e le Donne, Trapani 2013, 13-60. 
JAUBert A., Notes, w: SCh 167, Paris 1971.

JEFFERs J.S., Jewish and Christian Families in First-Century Rome, w: Judaism and Christianity in First-Century Rome, ed. K.P. Donfried - P. Richardson, Grand Rapids (Michigan) $1998,128-150$.

Mazzucco C., I Padri Apostolici, w: Donna e matrimonio alle origini della Chiesa, a cura di E. dal Covolo, Biblioteca di Scienze Religiose 122, Roma 1996, 9-40.

Prinzivalli E., Commento, w: Seguendo Gesù, Testi Cristiani delle Origini (= TCO) 1, Milano 2010, 449-541.

Trevett C., Christian Women and the Time of the Apostolic Fathers. Corinth, Rome and Asia Minor, Cardiff 2006.

Widok N., Droga dążenia do świętości wedtug Klemensa Rzymskiego, VoxP 32 (2012) t. $57,721-729$. 
